九州大学学術情報リポジトリ

Kyushu University Institutional Repository

Factors Affecting to Somatic Embryogenesis and Plant Regeneration from Callus and In Vitro Ontogeny of Doritaenopsis Taisuco Ladylip

Liao, Yu-Wan

Department of Horticulture, National Taiwan University

Huang, Pung-Ling

Department of Horticulture, National Taiwan University

Huang, Kuang-Liang

Department of Horticultural Science, National Chiayi University

Mi yaj ima, Ikuo

Institute of Tropical Agriculture, Kyushu University : Associate Professor

他

https://doi. org/10.5109/1526291

出版情報：九州大学大学院農学研究院紀要. 60 (1)，pp.13-22，2015-02-27. Faculty of Agriculture， Kyushu University

バージョン：

権利関係 : 


\title{
Factors Affecting to Somatic Embryogenesis and Plant Regeneration from Callus and In Vitro Ontogeny of Doritaenopsis Taisuco Ladylip
}

\author{
Yu-Wan LIAO ${ }^{1}$, Pung-Ling HUANG ${ }^{1}$, Kuang-Liang HUANG ${ }^{2}$, \\ Ikuo MIYAJIMA ${ }^{3}$ and Shan-Te HSU ${ }^{2 *}$ \\ Institute of Tropical Agriculture, Kyushu University, \\ Fukuoka 812-8581, Japan \\ (Received October 20, 2014 and accepted November 14, 2014)
}

\begin{abstract}
The efficient plant regeneration protocols were developed for Doritaenopsis Taisuco Ladylip through callus culture and somatic embryogenesis. The embryogenic calli were cultured on half strength Murashige and Skoog (MS) medium supplemented with $0.5 \mathrm{mg} \cdot \mathrm{L}^{-1}$ thidiazuron, $2.5 \mathrm{mg} \cdot \mathrm{L}^{-1}$ 2,4-dichlorophenoxyacetic acid, $30 \mathrm{~g} \cdot \mathrm{L}^{-1}$ sucrose and $3 \mathrm{~g} \cdot \mathrm{L}^{-1}$ Gelrite for proliferation. Basal salts, carbohydrate of medium obviously affected the somatic embryogenesis of callus. The highest frequency of somatic embryogenesis was obtained when embryogenic calli were cultured on half strength MS medium containing $20 \mathrm{~g} \cdot \mathrm{L}^{-1}$ maltose or $10 \mathrm{~g} \cdot \mathrm{L}^{-1}$ trehalose. The protocorm-like bodies well developed into plantlets after changing the basal salts to Hyponex, and carbohydrate to sucrose. The histological processing of somatic embryogenesis from callus was observed with light microscopy, and somatic embryo was clearly origin from single cell.
\end{abstract}

Key words: ammonium nitrate, carbohydrate, Phalaenopsis, protocorm-like body, somatic embryo

\section{INTRODUCTION}

Doritaenopsis genus is an intergeneric hybrid between Doritis and Phalaenopsis. In commercial practice, plants of Phalaenopsis, Doritis and Doritaenopsis are collectively named as phalaenopsis orchids. At present, the Royal Horticultural Society (RHS) committee has decided to sink Doritis into Phalaenopsis; therefore Doritis and Doritaenopsis are now considered to be Phalaenopsis by RHS (Royal Horticultural Society, 2013).

Phalaenopsis orchid has been a favorite consumer product due to its attractive color, graceful and longlasting flowers. Nowadays, pot phalaenopsis has become one of the most important orchids in the trade. For phalaenopsis orchid, an efficient plant regeneration system is beneficial for the micropropagation of selected elites and genetic transformation studies. Various micropropagation systems have been reported for micropropagating orchids; the generation of protocorm-like bodies (PLBs) is one of the important techniques (Arditti and Ernst, 1993). PLBs were first noted in the shoot-tip culture of Cymbidium orchid by Morel (1960). Since the general characteristics of growth and structure are similar to those of protocorms, the regenerated structures are termed PLBs.

PLBs of phalaenopsis can be induced directly from various explants, such as shoot tips (Tokuhara and Mii, 1993), flower stalk buds (Ichihashi, 1992), root tips

\footnotetext{
Department of Horticulture, National Taiwan University, Taipei 10617, Taiwan, ROC.

2 Department of Horticultural Science, National Chiayi University, Chiayi 60004, Taiwan, ROC.

Institute of Tropical Agriculture, Kyushu University, Fukuoka 812-8581, Japan

* Corresponding author (E-mail address: hsust@mail.ncyu.edu. tw, telephone: +88652717423 , fax: +88652775472 .)
}

(Tanaka et al., 1976), and leaf segments (Park et al., 2002). The indirect regeneration of PLBs from embryogenic callus culture has also been documented using solid (Ishii et al., 1998; Tokuhara and Mii, 2001) and liquid suspension cultures (Tokuhara and Mii, 2003). In the literature, it is often suggested that PLBs are somatic embryos simply based on morphology (Huan et al., 2004; Ishii et al., 1998) or that somatic embryogenesis is an early step in PLB formation (Zhao et al., 2008). Somatic embryogenesis is the development of somatic cells into differentiated plants through embryo stages under appropriate conditions (Zimmerman, 1993). Are PLBs somatic embryos? Do they take on characteristics similar to zygotic embryos prior to developing into PLBs? To answer these questions and to determine whether PLBs are indeed somatic embryos, we carried out a detailed ontogenetic study of PLBs from a friable embryogenic callus of Phalaenopsis using histological and histochemical methods (Lee et al., 2013). This study demonstrates that during the early stages of PLB formation, the cells show cytological characteristics and cell wall markers similar to zygotic embryo development, justifying the statement that PLBs are indeed somatic embryos of orchids.

At present, the various micropropagation systems have been developed for the research and the application of Doritaenopsis (Amaki and Higuchi, 1989; Chowdbury et al., 2003; Ernst, 1994; Islam et al., 2003; Islam and Ichihashi, 1999; Park, et al., 2002; Park et al., 2003; Tokuhara and Mii, 1993; Zhou, 1995). Although phalaenopsis seedling main production methods are by in vitro sowing, lateral bud of flower stalk culture and the protocorm-like body multiplication system, yet related researches are still continuous developing for mass production and genetic engineering. It is even more important, plant regeneration through somatic embryogenesis in genetic transformation has the certain superiority. The published reports about Doritaenopsis plant 
regeneration from callus were already considerable plentiful (Chowdbury et al., 2003; Islam and Ichihashi, 1999; Islam et al., 2003). Somatic embryogenesis offers vast potential as the method not only for clonal propagation but also genetic transformation. Therefore, in the view of long-term researches of molecular breeding in phalaenopsis, it is necessary to establish the cell culture systems of high regeneration efficiency and demand for genetic transformation.

\section{MATERIALS AND METHODS}

\section{Plant material and callus proliferation}

The initial callus was generated from in vitro grown protocorms of the breeding line Doritaenopsis Taisuco Ladylip. The callus was cultured and maintained on 1/2-strength macroelements and full-strength microelements of Murashige and Skoog (MS) medium (Murashige and Skoog, 1962) supplemented with $100 \mathrm{mg} \cdot \mathrm{L}^{-1}$ glutamine, $1 \mathrm{mg} \cdot \mathrm{L}^{-1}$ biotin, $100 \mathrm{mg} \cdot \mathrm{L}^{-1}$ myo-inositol, $30 \mathrm{~g} \cdot \mathrm{L}^{-1}$ sucrose, $3 \mathrm{~g} \cdot \mathrm{L}^{-1}$ Gelrite, $2.5 \mathrm{mg} \cdot \mathrm{L}^{-1}$ 2,4-dichlorophenoxyacetic acid $(2,4-\mathrm{D})$, and $0.5 \mathrm{mg} \cdot \mathrm{L}^{-1}$ thidiazuron (TDZ). The $\mathrm{pH}$ of the medium was adjusted to 5.7 with $1 \mathrm{~N} \mathrm{KOH}$ prior to autoclaving at $121^{\circ} \mathrm{C}$ for $20 \mathrm{~min}$. The callus was incubated in darkness at $25 \pm 2^{\circ} \mathrm{C}$.

The same medium as above and another six media with different supplements of plant growth regulators, including 2 or $3 \mathrm{mg} \cdot \mathrm{L}^{-1} 2,4-\mathrm{D}$ combined with $0,0.1$ or $1.0 \mathrm{mg} \cdot \mathrm{L}^{-1} \mathrm{TDZ}$, were prepared by the same protocol as above and adopted to test the effect of plant growth regulator treatments on callus proliferation. Each treatment contained $0.2 \mathrm{~g}$ fresh weight callus per $9-\mathrm{cm}$ diameter plastic Petri dish containing $20 \mathrm{~mL}$ medium with four replicate dishes. Data were scored after six weeks of culture in darkness at $25 \pm 2^{\circ} \mathrm{C}$.

\section{Somatic embryogenesis and PLB formation}

For somatic embryogenesis and PLB formation from callus, 1/2 strength MS basal media (1/2 MS) containing $100 \mathrm{mg} \cdot \mathrm{L}^{-1}$ glutamine, $1 \mathrm{mg} \cdot \mathrm{L}^{-1}$ biotin, $100 \mathrm{mg} \cdot \mathrm{L}^{-1}$ myoinositol, $3 \mathrm{~g} \cdot \mathrm{L}^{-1}$ Gelrite supplemented with three types of carbohydrates (sucrose [Bio Basic INC.], maltose [Sigma] and trehalose [Sigma]) at concentration of 5, 10 and $20 \mathrm{~g} \cdot \mathrm{L}^{-1}$, and two combinations of plant growth regulators (2 or $3 \mathrm{mg} \cdot \mathrm{L}^{-1} 2,4-\mathrm{D}$ combined with $1 \mathrm{mg} \cdot \mathrm{L}^{-1} \mathrm{TDZ}$ ) separately were prepared by the same protocol as above and adopted to evaluate the effects of different types and concentrations of carbohydrate source, and growth regulator combinations.

This three-factorial experiment was carried out in terms of a completely randomized design with 18 different treatments and four replicates of each treatment. Calli gained on media containing $2 \mathrm{mg} \cdot \mathrm{L}^{-1} 2,4-\mathrm{D}+1 \mathrm{mg} \cdot \mathrm{L}^{-1}$ TDZ and $3 \mathrm{mg} \cdot \mathrm{L}^{-1} 2,4-\mathrm{D}+1 \mathrm{mg} \cdot \mathrm{L}^{-1}$ TDZ from prior experiment of callus proliferation were respectively used for treatments with 2 and $3 \mathrm{mg} \cdot \mathrm{L}^{-1} 2,4-\mathrm{D}$ combined with $1 \mathrm{mg} \cdot \mathrm{L}^{-1} \mathrm{TDZ}$ in this experiment. For each replicate, the $0.3 \mathrm{~g}$ fresh weight callus initially divided into 10 masses was inoculated on a $9-\mathrm{cm}$ Petri dish containing $20 \mathrm{ml}$ medium. Data were scored after three months of culture at $25 \pm 2^{\circ} \mathrm{C}$ with $16 \mathrm{~h}$ light $/ 8 \mathrm{~h}$ dark and photon flux of 22-35 $\mu \mathrm{mol} \cdot \mathrm{m}^{-2} \cdot \mathrm{s}^{-1}$ (daylight fluorescent tube FL-20D/18; $20 \mathrm{~W}$ ). The events investigated included the fresh weight and number of PLBs formed from callus. The osmotic pressure of media without solidifying agent were also measured by osmometer (5500 Vapor pressure osmometer, Wescor Inc.), and in unit of $\mathrm{mOsm} \cdot \mathrm{kg}^{-1}$.

\section{Plantlet growth and development}

To investigate the effects of sucrose and ammonium nitrate concentrations on growth of plantlet regenerated from callus, tests were done as a two-factorial experiment in a completely randomized design with 9 different treatments and four replicates of each treatment.

PLBs regenerated from prior experiment of somatic embryogenesis and PLB formation were separately cultured on basal media containing $3 \mathrm{~g} \cdot \mathrm{L}^{-1}$ Hyponex\#1, $0.1 \mathrm{~g} \cdot \mathrm{L}^{-1}$ citric acid, $1 \mathrm{~g} \cdot \mathrm{L}^{-1}$ tryptone-peptone, $1 \mathrm{~g} \cdot \mathrm{L}^{-1}$ activated charcoal, $8 \mathrm{~g} \cdot \mathrm{L}^{-1}$ agar supplemented with sucrose at concentration of 10,20 and $30 \mathrm{~g} \cdot \mathrm{L}^{-1}$, and ammonium nitrate at concentration of $0,412.5$ (1/4 MS) and $825.0 \mathrm{mg} \cdot \mathrm{L}^{-1}$ (1/2 MS). The $\mathrm{pH}$ of the media was adjusted to 5.6 prior to autoclaving. Ten PLBs (on average $0.15 \mathrm{~g}$ fresh mass) were placed on a $9 \mathrm{~cm}$ Petri dish containing $20 \mathrm{~mL}$ solid medium. Each Petri dish was regarded as a replicate. After three months of culture at $25 \pm 2^{\circ} \mathrm{C}$ with $16 \mathrm{~h} \mathrm{light} / 8 \mathrm{~h}$ dark and photon flux of $22-35 \mu \mathrm{mol} \cdot \mathrm{m}^{-2} \cdot \mathrm{s}^{-1}$, explants were evaluated in terms of plantlet growth indexes including weight, number and length of leaf and root.

\section{Morphological and histological investigations}

Cytological observations were begun at the onset of somatic embryogenesis. The materials were observed and taken pictures in the stereomicroscope (Olympus SZXRFA) and were squashed and examined using a light microscope (Zeiss Axioskop2). For histological observations, samples were fixed in FAA solution (70\% ethanol, $5 \%$ glacial acetic acid, and 5\% formaldehyde) for 24 hours in room temperature, then were dehydrated with a graded series of ethanol and butanol solutions and embedded in paraffin referred to Berlyn and Miksche (1976). Tissue was sectioned at $8-10 \mathrm{~mm}$ thickness, stained with Delafield's hematoxylin solution (Merck, Germany) for $10 \mathrm{~min}$, and examined under a light microscope (Zeiss Axioskop2).

\section{RESULTS}

\section{Effect of 2,4-D and TDZ on callus proliferation}

This experiment was performed to evaluate the effects of the type and concentration of plant growth regulators on callus proliferation in Doritaenopsis Taisuco Ladylip. In this study the effects of 2,4-D and TDZ at various concentrations were tested for their potential on callus fresh weight gain and morphogenetic change. The combination of $2 \mathrm{mg} \cdot \mathrm{L}^{-1} 2,4-\mathrm{D}$ and $1 \mathrm{mg} \cdot \mathrm{L}^{-1} \mathrm{TDZ}$ or $2.5 \mathrm{mg} \cdot \mathrm{L}^{-1} 2,4-\mathrm{D}$ and $0.5 \mathrm{mg} \cdot \mathrm{L}^{-1} \mathrm{TDZ}$ were most effective on callus fresh weight. The reduction of TDZ concentration decreased callus fresh weight. When 2 or $3 \mathrm{mg} \cdot \mathrm{L}^{-1}$ 
2,4-D was combined without TDZ, necrotic browning callus was formed (Table 1). Under the TDZ supple- ment, the calli looked more fresh yellow in $3 \mathrm{mg} \cdot \mathrm{L}^{-1}$ 2,4-D than in $2 \mathrm{mg} \cdot \mathrm{L}^{-1} 2,4-\mathrm{D}$ (Fig. 1A).

Table 1. Effect of 2,4-dichlorophenoxyacetic acid (2,4-D) and thidiazuron (TDZ) on callus proliferation in Doritaenopsis Taisuco Ladylip

\begin{tabular}{|c|c|c|c|c|}
\hline \multicolumn{2}{|c|}{ Plant growth regulators $\left(\mathrm{mg} \cdot \mathrm{L}^{-1}\right)$} & \multicolumn{3}{|c|}{ Callus } \\
\hline $2,4-\mathrm{D}$ & TDZ & Fresh weight (g) & Increased weight (\%) & Morphology \\
\hline 2.0 & 0 & $0.3 \mathrm{~d}$ & $48 d$ & Browning death \\
\hline 2.0 & 0.1 & $1.0 \mathrm{bc}$ & $416 \mathrm{bc}$ & \\
\hline 2.0 & 1.0 & $1.4 \mathrm{a}$ & 616 a & \\
\hline 2.5 & 0.5 & $1.3 \mathrm{a}$ & 558 a & \\
\hline 3.0 & 0 & $0.3 \mathrm{~d}$ & $51 \mathrm{~d}$ & Browning death \\
\hline 3.0 & 0.1 & $0.9 \mathrm{c}$ & $358 \mathrm{c}$ & \\
\hline 3.0 & 1.0 & $1.1 \mathrm{~b}$ & $466 \mathrm{~b}$ & \\
\hline
\end{tabular}

Basal medium was 1/2 MS, $100 \mathrm{mg} \cdot \mathrm{L}^{-1}$ glutamine, $1 \mathrm{mg} \cdot \mathrm{L}^{-1}$ biotin, $100 \mathrm{mg} \cdot \mathrm{L}^{-1}$ myo-inositol, $30 \mathrm{~g} \cdot \mathrm{L}^{-1} \mathrm{sucrose}$, $3 \mathrm{~g} \cdot \mathrm{L}^{-1}$ Gelrite, $\mathrm{pH} 5.7$.

For each treatment, four replicates of $0.2 \mathrm{~g}$ callus in each dish were cultured.

Data were scored after six weeks of culture in the dark.

Means separated within columns by Duncan's multiple range test at $P \leq 0.05$.
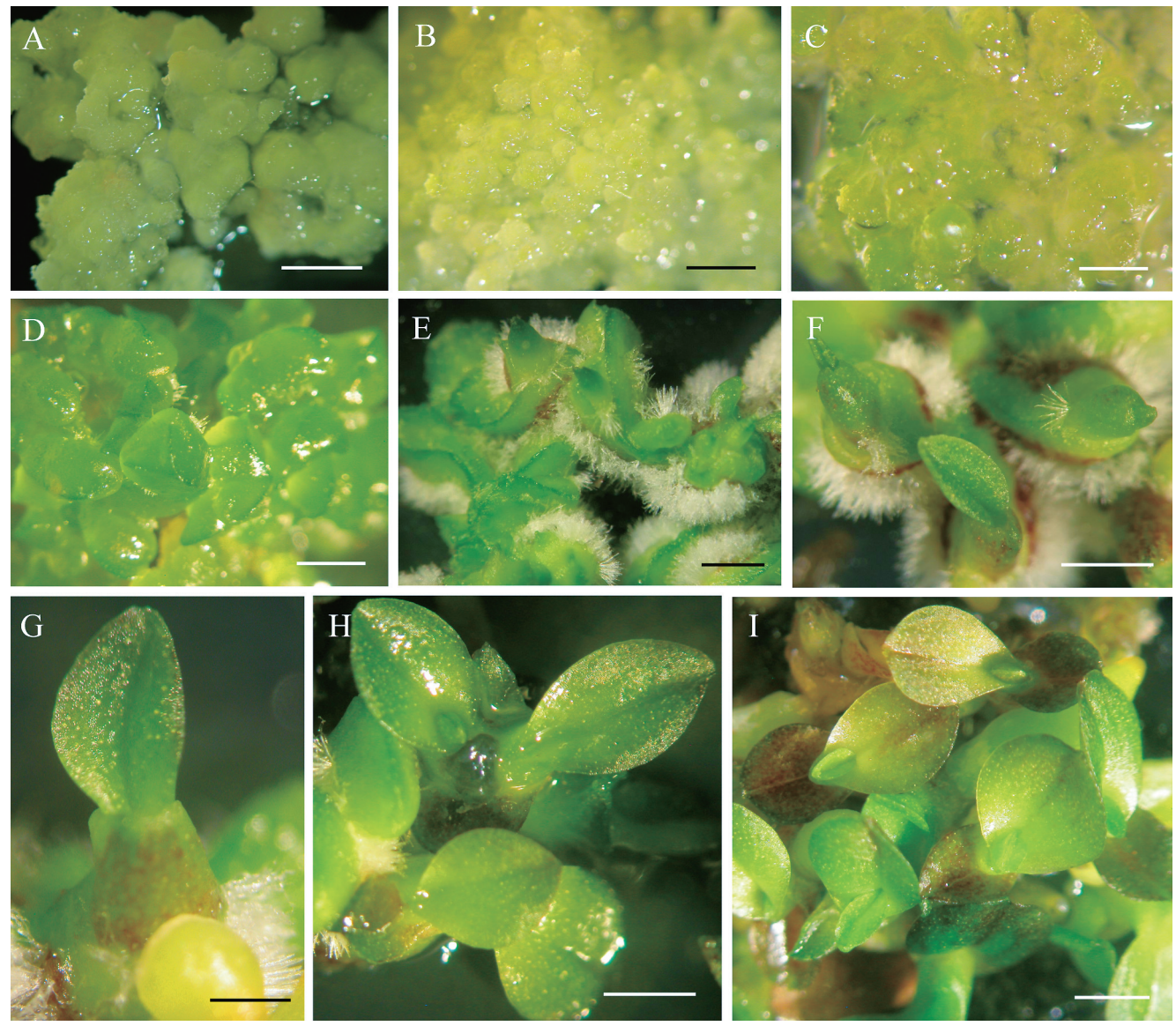

Fig. 1. Plant regeneration through somatic embryogenesis of callus in Doritaenopsis Taisuco Ladylip. Continuous subculturing of the initial callus derived from in vitro grown protocorms resulted in the formation of the friable yellowish-white embryogenic callus (A). After transferred to the protocormlike body (PLB) induction medium, the callus gradually turned greenish (B) and then gave rise to some of initial PLBs within two months of culture (C). After three months culture, somatic embryos developed to PLBs with morphological and functional polarity (D). Rhizoids formed on surface of mature PLBs with leaves after five months of culture (E, F), and roots protruded after six months of culture $(\mathrm{G}, \mathrm{H})$. PLBs developed into intact plantlets within seven months of culture (I). Bar=2 mm (A, D, E, F, H, I) ; 1 mm (B, C, G). 
Effects of different types and concentrations of carbohydrate source, and growth regulator combinations on somatic embryogenesis and PLB formation from callus

This three-factorial experiment was carried out to investigate the effects of maltose, trehalose and sucrose at various concentrations, and two growth regulator combinations on somatic embryogenesis and PLB formation from callus in Doritaenopsis Taisuco Ladylip. Significant differences in fresh weight gain, PLB formation and plantlet development were all observed among the types and concentrations of carbohydrate source tested (Table 2 ); however the interactions between the types and concentrations of carbohydrate source were also significant. Calli gained on media containing $2 \mathrm{mg} \cdot \mathrm{L}^{-1} 2,4-\mathrm{D}+1 \mathrm{mg} \cdot \mathrm{L}^{-1}$ TDZ (D2T1) and $3 \mathrm{mg} \cdot \mathrm{L}^{-1} 2,4-\mathrm{D}+1 \mathrm{mg} \cdot \mathrm{L}^{-1} \mathrm{TDZ}$ (D3T1) from prior experiment of callus proliferation and respectively used for treatments with 2 and $3 \mathrm{mg} \cdot \mathrm{L}^{-1}$ 2,4-D combined with $1 \mathrm{mg} \cdot \mathrm{L}^{-1} \mathrm{TDZ}$ had no significant effect on fresh weight gain, PLB formation and plantlet development (Table 2). In addition, the two-factor interaction between type of carbohydrate source and growth regulator combination and the interaction between concentration of carbohydrate source and growth regulator combination, and the three-factor interaction between type and concentration of carbohydrate source and growth regulator combination were all not significant (Table 2).

The rise of concentration in all three carbohydrates tended to increase explant fresh weight, although the treatments employed trehalose at concentration of $20 \mathrm{~g} \cdot \mathrm{L}^{-1}$ were the most ones (Table 3 ). The treatments used sucrose at concentration of $20 \mathrm{~g} \cdot \mathrm{L}^{-1}$ were no useful on PLB formation (Table 3), the explants still remained in a callus stage. When sucrose was supplemented at 5 and $10 \mathrm{~g} \cdot \mathrm{L}^{-1}$, the formation of the PLBs were observed (Table 3); however the PLBs were almost smaller than $2 \mathrm{~mm}$ in diameter in treatments of sucrose at $10 \mathrm{~g} \cdot \mathrm{L}^{-1}$. The treatments employed maltose at concentration of 10 and $20 \mathrm{~g} \cdot \mathrm{L}^{-1}$ and trehalose at $10 \mathrm{~g} \cdot \mathrm{L}^{-1}$ were most effective on PLB formation in quantity (Table 3), about 300 PLBs were produced from each $0.3 \mathrm{~g}$ callus after three months of culture.

Comparing the development of PLB with three different carbohydrates, based on the proportion of PLBs with leaf, it was observed that maltose was the most effective carbohydrate source with average of $12.4 \%$, obviously higher than $8.7 \%$ of the trehalose and $2.8 \%$ of the sucrose (Table 2). To simultaneously take account of the root development, maltose at $20 \mathrm{~g} \cdot \mathrm{L}^{-1}$ was obvious the best choice for PLB formation and development (Table 3).

Table 2. Analysis of variance for the effects of three different disaccharides and concentrations, and two growth regulator combinations on fresh weight and the protocorm-like body (PLB) formation from the callus in Doritaenopsis Taisuco Ladylip

\begin{tabular}{|c|c|c|c|c|c|c|}
\hline Treatments & $\begin{array}{c}\text { Fresh } \\
\text { weight } \\
\text { (g) }\end{array}$ & $\begin{array}{c}\text { No. of } \\
\operatorname{PLB}(>2 \mathrm{~mm}) \\
\text { (A) }\end{array}$ & $\begin{array}{c}\text { No. of } \\
\text { PLB with } \\
\text { leaf(>2 mm) } \\
\text { (B) }\end{array}$ & $\begin{array}{c}\text { No. of } \\
\text { PLB with } \\
\text { leaf }(>2 \mathrm{~mm}) \\
\text { (C) }\end{array}$ & $\begin{array}{l}((\mathrm{B}+\mathrm{C}) / \mathrm{A}) \\
\quad * 100\end{array}$ & $\begin{array}{l}\text { No. of } \\
\text { PLB with } \\
\text { root }\end{array}$ \\
\hline maltose & $3.7 \mathrm{~b}$ & $256.1 \mathrm{a}$ & $30.0 \mathrm{a}$ & $3.4 \mathrm{a}$ & $12.4 \mathrm{a}$ & $2.9 \mathrm{a}$ \\
\hline trehalose & $4.8 \mathrm{a}$ & $158.6 \mathrm{~b}$ & $15.5 \mathrm{~b}$ & $1.8 \mathrm{~b}$ & $8.7 \mathrm{~b}$ & $1.3 \mathrm{a}$ \\
\hline sucrose & $3.9 \mathrm{~b}$ & $20.0 \mathrm{c}$ & $1.0 \mathrm{c}$ & $0.5 \mathrm{c}$ & $2.8 \mathrm{c}$ & $0.0 \mathrm{c}$ \\
\hline Carbo & $* * *$ & $* * *$ & $* * *$ & $* * *$ & $* * *$ & $* * *$ \\
\hline $5 \mathrm{~g} \cdot \mathrm{L}^{-1}$ & $2.3 \mathrm{c}$ & $109.3 \mathrm{~b}$ & $5.9 \mathrm{~b}$ & $0.9 \mathrm{~b}$ & $6.9 \mathrm{a}$ & $0.4 \mathrm{~b}$ \\
\hline $10 \mathrm{~g} \cdot \mathrm{L}^{-1}$ & $4.7 \mathrm{~b}$ & 204.8 a & $22.6 \mathrm{a}$ & $2.7 \mathrm{a}$ & $8.5 \mathrm{a}$ & $2.0 \mathrm{a}$ \\
\hline $20 \mathrm{~g} \cdot \mathrm{L}^{-1}$ & $5.4 \mathrm{a}$ & $120.7 \mathrm{~b}$ & $18.0 \mathrm{a}$ & $2.1 \mathrm{ab}$ & $8.5 \mathrm{a}$ & $1.9 \mathrm{a}$ \\
\hline Con & $* * *$ & $* * *$ & $* * *$ & $* *$ & ns & $*$ \\
\hline Carbo * Con & $* * *$ & $* * *$ & $* * *$ & $* * *$ & $* * *$ & $* * *$ \\
\hline D2T1 & $4.1 \mathrm{a}$ & $144.2 \mathrm{a}$ & $16.1 \mathrm{a}$ & $2.1 \mathrm{a}$ & $8.4 \mathrm{a}$ & $1.3 \mathrm{a}$ \\
\hline D3T1 & $4.1 \mathrm{a}$ & 145.7 a & $14.9 \mathrm{a}$ & $1.7 \mathrm{a}$ & $7.5 \mathrm{a}$ & $1.5 \mathrm{a}$ \\
\hline DT & ns & ns & ns & ns & ns & ns \\
\hline Carbo * DT & ns & ns & ns & ns & ns & ns \\
\hline Con* DT & ns & ns & ns & ns & ns & ns \\
\hline Carbo * Con* DT & ns & ns & ns & ns & ns & ns \\
\hline
\end{tabular}

Calli gained on media containing $2 \mathrm{mg} \cdot \mathrm{L}^{-1} 2,4$-dichlorophenoxyacetic acid $(2,4-\mathrm{D})+1 \mathrm{mg} \cdot \mathrm{L}^{-1}$ thidiazuron (TDZ) (D2T1) and $3 \mathrm{mg} \cdot \mathrm{L}^{-1} 2,4-\mathrm{D}+1 \mathrm{mg} \cdot \mathrm{L}^{-1} \mathrm{TDZ}$ (D3T1) from prior experiment of callus proliferation were respectively used for treatments with 2 and $3 \mathrm{mg} \cdot \mathrm{L}^{-1} 2,4-\mathrm{D}$ combined with $1 \mathrm{mg} \cdot \mathrm{L}^{-1} \mathrm{TDZ}$ in this experiment.

Basal medium supplemented with $1 / 2 \mathrm{MS}, 100 \mathrm{mg} \cdot \mathrm{L}^{-1}$ glutamine, $1 \mathrm{mg} \cdot \mathrm{L}^{-1}$ biotin, $100 \mathrm{mg} \cdot \mathrm{L}^{-1} \mathrm{myo}-\mathrm{inositol}, 3 \mathrm{~g} \cdot \mathrm{L}^{-1} \mathrm{Gelrite}$, $\mathrm{pH} 5.7$. For each treatment, four replicates of $0.3 \mathrm{~g}$ callus in each dish were cultured. Data were scored after three months of culture at $25 \pm 2^{\circ} \mathrm{C}$ with $16 \mathrm{~h}$ light $/ 8 \mathrm{~h}$ dark and photon flux of $22-35 \mu \mathrm{mol} \cdot \mathrm{m}^{-2} \cdot \mathrm{s}^{-1}$.

Means separated within columns by Duncan's multiple range test at $P \leq 0.05$.

NS, ***,***: Not significant or significant at $P \leq 0.05,0.01$, or 0.001 , respectively. 
Table 3. Effects of three different disaccharides and concentrations, and two growth regulator combinations on fresh weight and the protocorm-like body (PLB) formation from the callus in Doritaenopsis Taisuco Ladylip

\begin{tabular}{|c|c|c|c|c|c|c|c|c|c|c|}
\hline $\begin{array}{l}\text { Callus from } \\
\text { the culture } \\
\text { medium }\end{array}$ & $\begin{array}{l}\text { Carbo- } \\
\text { hydrate }\end{array}$ & $\begin{array}{l}\text { Conc. } \\
\left(\mathrm{g} \cdot \mathrm{L}^{-1}\right)\end{array}$ & $\mathrm{mOsm} \cdot \mathrm{kg}^{-1}$ & $\begin{array}{l}\text { F.W. } \\
(\mathrm{g})\end{array}$ & $\begin{array}{l}\text { No. of PLB } \\
(>0.2 \mathrm{~mm}) \\
\text { (A) }\end{array}$ & $\begin{array}{l}\text { No. of PLB } \\
\text { with leaf } \\
(<2 \mathrm{~mm}) \\
\text { (B) }\end{array}$ & $\begin{array}{l}\text { No. of PLB } \\
\text { with leaf } \\
(>0.2 \mathrm{~mm}) \\
\text { (C) }\end{array}$ & $\begin{array}{c}((\mathrm{B}+\mathrm{C}) / \mathrm{A}) * \\
100\end{array}$ & $(\mathrm{C} / \mathrm{A})^{*} 100$ & $\begin{array}{l}\text { No. of PLB } \\
\text { with root }\end{array}$ \\
\hline \multirow[t]{9}{*}{ D2T1 } & maltose & 5 & 68 & $2.1 \mathrm{e}$ & $119.3 \mathrm{~cd}$ & $0.5 \mathrm{~d}$ & $7.5 \mathrm{~d}$ & $8.1 \mathrm{de}$ & 7.6de & $0.3 \mathrm{~d}$ \\
\hline & & 10 & 83 & $4.2 \mathrm{~d}$ & $347.0 \mathrm{a}$ & $2.8 \mathrm{bcd}$ & $30.3 c$ & $9.5 \mathrm{cde}$ & $8.7 \mathrm{bcde}$ & $2.8 \mathrm{bcd}$ \\
\hline & & 20 & 110 & $4.6 \mathrm{~cd}$ & $289.3 b$ & $8.8 \mathrm{a}$ & $52.5 \mathrm{a}$ & $21.2 \mathrm{a}$ & $17.8 \mathrm{a}$ & $4.8 \mathrm{ab}$ \\
\hline & trehalose & 5 & 66 & $1.9 \mathrm{e}$ & $141.8 \mathrm{c}$ & $0.3 \mathrm{~d}$ & $5.3 \mathrm{~d}$ & $4.0 \mathrm{ef}$ & $3.7 \mathrm{ef}$ & $0.8 \mathrm{~cd}$ \\
\hline & & 10 & 79 & $5.5 \mathrm{~b}$ & $276.3 \mathrm{~b}$ & $6.0 \mathrm{ab}$ & $40.8 \mathrm{abc}$ & $17.1 \mathrm{ab}$ & $14.9 \mathrm{abc}$ & $3.0 \mathrm{bcd}$ \\
\hline & & 20 & 109 & $6.8 \mathrm{a}$ & $71.3 \mathrm{de}$ & $0.0 \mathrm{~d}$ & $4.5 \mathrm{~d}$ & $5.8 \mathrm{ef}$ & $5.8 \mathrm{ef}$ & $0.5 \mathrm{~cd}$ \\
\hline & sucrose & 5 & 69 & $2.6 \mathrm{e}$ & $47.5 \mathrm{ef}$ & $1.0 \mathrm{~d}$ & $4.3 \mathrm{~d}$ & $10.4 \mathrm{bcde}$ & 8.4cde & $0.0 \mathrm{~d}$ \\
\hline & & 10 & 82 & $4.3 \mathrm{~d}$ & $5.3 \mathrm{f}$ & $0.0 \mathrm{~d}$ & $0.0 \mathrm{~d}$ & $0.0 \mathrm{f}$ & $0.0 \mathrm{f}$ & $0.0 \mathrm{~d}$ \\
\hline & & 20 & 113 & $5.2 \mathrm{bc}$ & $0.0 \mathrm{f}$ & $0.0 \mathrm{~d}$ & $0.0 \mathrm{~d}$ & $0.0 \mathrm{f}$ & $0.0 \mathrm{f}$ & $0.0 \mathrm{~d}$ \\
\hline \multirow[t]{9}{*}{ D3T1 } & maltose & 5 & 68 & $2.3 \mathrm{e}$ & $145.3 \mathrm{c}$ & $1.8 \mathrm{~cd}$ & $12.5 \mathrm{~d}$ & $9.5 \mathrm{cde}$ & 8.3de & $0.3 \mathrm{~d}$ \\
\hline & & 10 & 83 & $4.2 \mathrm{~d}$ & $312.5 \mathrm{ab}$ & $2.8 \mathrm{bcd}$ & $28.5 \mathrm{c}$ & $10.0 \mathrm{bcde}$ & 9.1 bcde & $3.5 \mathrm{abc}$ \\
\hline & & 20 & 110 & $4.6 \mathrm{~cd}$ & $323.5 \mathrm{ab}$ & $3.8 \mathrm{bcd}$ & $49.0 \mathrm{ab}$ & $16.2 \mathrm{abc}$ & 15.1ab & $6.0 \mathrm{a}$ \\
\hline & trehalose & 5 & 66 & $2.0 \mathrm{e}$ & $141.0 \mathrm{c}$ & $0.0 \mathrm{~d}$ & $4.3 \mathrm{~d}$ & $2.9 \mathrm{ef}$ & $2.9 \mathrm{ef}$ & $1.0 \mathrm{~cd}$ \\
\hline & & 10 & 79 & $5.5 b$ & $281.5 b$ & $4.8 \mathrm{bc}$ & $36.0 \mathrm{bc}$ & 14.4abcd & $12.8 \mathrm{abcd}$ & $2.8 \mathrm{bcd}$ \\
\hline & & 20 & 109 & $7.0 \mathrm{a}$ & $40.0 \mathrm{ef}$ & $0.0 \mathrm{~d}$ & $2.0 \mathrm{~d}$ & 8.0de & 8.0de & $0.0 \mathrm{~d}$ \\
\hline & sucrose & 5 & 69 & $2.5 \mathrm{e}$ & $61.0 \mathrm{e}$ & $2.0 \mathrm{~cd}$ & $1.8 \mathrm{~d}$ & $6.2 \mathrm{ef}$ & $2.5 \mathrm{ef}$ & $0.3 \mathrm{~d}$ \\
\hline & & 10 & 82 & $4.4 \mathrm{~cd}$ & $6.5 \mathrm{f}$ & $0.0 \mathrm{~d}$ & $0.0 \mathrm{~d}$ & $0.0 \mathrm{f}$ & $0.0 \mathrm{f}$ & $0.0 \mathrm{~d}$ \\
\hline & & 20 & 113 & $4.5 \mathrm{~cd}$ & $0.0 \mathrm{f}$ & $0.0 \mathrm{~d}$ & $0.0 \mathrm{~d}$ & $0.0 \mathrm{f}$ & $0.0 \mathrm{f}$ & $0.0 \mathrm{~d}$ \\
\hline
\end{tabular}

Calli gained on media containing $2 \mathrm{mg} \cdot \mathrm{L}^{-1} 2,4$-dichlorophenoxyacetic acid $(2,4-\mathrm{D})+1 \mathrm{mg} \cdot \mathrm{L}^{-1}$ thidiazuron (TDZ) (D2T1) and $3 \mathrm{mg} \cdot \mathrm{L}^{-1}$ 2,4-D+1 mg. $\mathrm{L}^{-1} \mathrm{TDZ}$ (D3T1) from prior experiment of callus proliferation were respectively used for treatments with 2 and $3 \mathrm{mg} \cdot \mathrm{L}^{-1}$ 2,4-D combined with $1 \mathrm{mg} \cdot \mathrm{L}^{-1} \mathrm{TDZ}$ in this experiment.

Basal medium supplemented with $1 / 2 \mathrm{MS}, 100 \mathrm{mg} \cdot \mathrm{L}^{-1}$ glutamine, $1 \mathrm{mg} \cdot \mathrm{L}^{-1}$ biotin, $100 \mathrm{mg} \cdot \mathrm{L}^{-1} \mathrm{myo}-$ inositol, $3 \mathrm{~g} \cdot \mathrm{L}^{-1} \mathrm{Gelrite}$, $\mathrm{pH} 5.7$.

For each treatment, four replicates of $0.3 \mathrm{~g}$ callus in each dish were cultured. Data were scored after three months of culture at $25 \pm 2^{\circ} \mathrm{C}$ with $16 \mathrm{~h}$ light $/ 8 \mathrm{~h}$ dark and photon flux of $22-35 \mu \mathrm{mol} \cdot \mathrm{m}^{-2} \cdot \mathrm{s}^{-1}$.

Means separated within columns by Duncan's multiple range test at $P \leq 0.05$.

\section{Effects of sucrose and ammonium nitrate concen- trations on growth of plantlet regenerated from callus}

This two-factorial experiment was carried out to evaluate the effects of sucrose and ammonium nitrate concentrations on growth of plantlet regenerated from callus in Doritaenopsis Taisuco Ladylip. No significant differences in total number of leaves, total leaf length and weight measured per treatment were observed among the sucrose concentrations as well as among the ammonium nitrate concentrations tested (Table 4). However, significant differences in total number of roots, total root length and weight measured per treatment were all observed among the sucrose and ammonium nitrate concentrations (Table 4); in addition, the interactions between the sucrose and ammonium nitrate concentrations were not significant. Among the sucrose concentrations, treatments of $30 \mathrm{~g} \cdot \mathrm{L}^{-1}$ gave the highest total number of roots and $10 \mathrm{~g} \cdot \mathrm{L}^{-1}$ the poorest, and treatments of 20 and $30 \mathrm{~g} \cdot \mathrm{L}^{-1}$ offered both the highest total root length and weight (Table 4). Among the ammonium nitrate concentrations, treatments without additional supplementation and treatments of $412.5 \mathrm{mg} \cdot \mathrm{L}^{-1}$ (half strength employed in MS) gave the highest total number of roots, and treatments without additional supplementation offered both the highest total root length and weight and $825.0 \mathrm{mg} \cdot \mathrm{L}^{-1}$ (quarter strength employed in MS medium) the least (Table 4).

In terms of the ratios of root to leaf in fresh weight, in length and in number, there were all significant differences among the sucrose and ammonium nitrate concentrations (Table 5); however the interactions between the sucrose and ammonium nitrate concentrations were not significant. Among the sucrose concentrations, treatments of $30 \mathrm{~g} \cdot \mathrm{L}^{-1}$ gave the highest ratios of root to leaf in fresh weight, in length and in number and $10 \mathrm{~g} \cdot \mathrm{L}^{-1}$ the least (Table 5). Among the ammonium nitrate concentrations, treatments without additional supplementation and treatments of $412.5 \mathrm{mg} \cdot \mathrm{L}^{-1}$ gave the highest ratios of root to leaf in fresh weight, and treatments without additional supplementation offered both the highest ratios of root to leaf in length and in number and $825.0 \mathrm{mg} \cdot \mathrm{L}^{-1}$ the least (Table 5).

In considering the growth and balance of root and shoot (Table 4 and 5), basal media containing $3 \mathrm{~g} \cdot \mathrm{L}^{-1}$ Hyponex\#1 supplemented with sucrose at concentration 
Table 4. Analysis of variance for the effects of sucrose and ammonium nitrate concentrations on growth of plantlet regenerated from callus in Doritaenopsis Taisuco Ladylip

\begin{tabular}{|c|c|c|c|c|c|c|c|c|}
\hline \multicolumn{3}{|c|}{ Treatments } & \multirow{2}{*}{$\begin{array}{c}\begin{array}{c}\text { Total no. of } \\
\text { leaves }\end{array} \\
32.0 \mathrm{a}\end{array}$} & \multirow{2}{*}{$\begin{array}{c}\begin{array}{c}\text { Total leaf } \\
\text { length }(\mathrm{cm})\end{array} \\
24.7 \mathrm{~b}\end{array}$} & \multirow{2}{*}{$\begin{array}{c}\begin{array}{c}\text { Total leaf } \\
\text { weight } \\
(\mathrm{g})\end{array} \\
1.2 \mathrm{a}\end{array}$} & \multirow{2}{*}{$\begin{array}{c}\begin{array}{c}\text { Total no. of } \\
\text { roots }\end{array} \\
22.0 \mathrm{c}\end{array}$} & \multirow{2}{*}{$\begin{array}{c}\begin{array}{c}\text { Total root } \\
\text { length }(\mathrm{cm})\end{array} \\
17.8 \mathrm{~b}\end{array}$} & \multirow{2}{*}{$\begin{array}{c}\begin{array}{c}\text { Total root } \\
\text { weight } \\
(\mathrm{g})\end{array} \\
0.5 \mathrm{~b}\end{array}$} \\
\hline Sucrose (A) & $\left(\mathrm{g} \cdot \mathrm{L}^{-1}\right)$ & 10 & & & & & & \\
\hline & & 20 & $30.1 \mathrm{a}$ & $27.5 \mathrm{a}$ & $1.4 \mathrm{a}$ & $32.3 \mathrm{~b}$ & $36.4 \mathrm{a}$ & $1.1 \mathrm{a}$ \\
\hline & & 30 & $31.0 \mathrm{a}$ & $25.0 \mathrm{ab}$ & $1.2 \mathrm{a}$ & $36.3 \mathrm{a}$ & $37.8 \mathrm{a}$ & $1.2 \mathrm{a}$ \\
\hline & & & ns & ns & ns & $* * *$ & $* * *$ & $* * *$ \\
\hline \multirow[t]{4}{*}{$\mathrm{NH}_{4} \mathrm{NO}_{3}$ (B) } & & 0 & $29.6 \mathrm{a}$ & $26.0 \mathrm{ab}$ & $1.3 \mathrm{a}$ & $33.8 \mathrm{a}$ & $1.2 \mathrm{a}$ & $37.4 \mathrm{a}$ \\
\hline & & $1 / 4 \mathrm{MS}$ & $31.8 \mathrm{a}$ & $27.2 \mathrm{a}$ & $1.2 \mathrm{a}$ & $30.9 a$ & $1.0 \mathrm{~b}$ & $30.8 b$ \\
\hline & & $1 / 2 \mathrm{MS}$ & $31.7 \mathrm{a}$ & $24.1 b$ & $1.2 \mathrm{a}$ & $25.9 \mathrm{~b}$ & $0.7 \mathrm{c}$ & $23.8 \mathrm{c}$ \\
\hline & & & ns & ns & ns & $* * *$ & $* * *$ & $* * *$ \\
\hline$A^{*} B$ & & & ns & ns & ns & ns & ns & ns \\
\hline
\end{tabular}

Basal medium supplemented with $3 \mathrm{~g} \cdot \mathrm{L}^{-1}$ Hyponex\#1, $0.1 \mathrm{~g} \cdot \mathrm{L}^{-1}$ citric acid, $1 \mathrm{~g} \cdot \mathrm{L}^{-1}$ tryptone-peptone, $1 \mathrm{~g} \cdot \mathrm{L}^{-1}$ activated charcoal, $8 \mathrm{~g} \cdot \mathrm{L}^{-1}$ agar, $\mathrm{pH} 5.6$.

Concentration of ammonium nitrate $\left(\mathrm{NH}_{4} \mathrm{NO}_{3}\right): 1 / 4 \mathrm{MS}\left(412.5 \mathrm{mg} \cdot \mathrm{L}^{-1}\right), 1 / 2 \mathrm{MS}\left(825.0 \mathrm{mg} \cdot \mathrm{L}^{-1}\right)$

For each treatment, four replicates of ten protocorm-like bodies (on average $0.15 \mathrm{~g}$ fresh mass) were cultured. Data were scored after three months of culture at $25 \pm 2^{\circ} \mathrm{C}$ with $16 \mathrm{~h}$ light $/ 8 \mathrm{~h}$ dark and photon flux of $22-35 \mu \mathrm{mol} \cdot \mathrm{m}^{-2} \cdot \mathrm{s}^{-1}$.

Values followed by the same letter are not significantly different at $P \leq 0.05$. NS, ***: Not significant or significant at $P \leq$ 0.001, respectively (two-way ANOVA, Duncan's multiple range test).

Table 5. Analysis of variance for the effects of sucrose and ammonium nitrate concentrations on root/leaf ratio of plantlet regenerated from callus in Doritaenopsis Taisuco Ladylip

\begin{tabular}{|c|c|c|c|c|c|}
\hline \multirow{2}{*}{\multicolumn{3}{|c|}{ Treatments }} & \multicolumn{3}{|c|}{ Root/leaf ratio } \\
\hline & & & \multirow{2}{*}{$\frac{\text { Fresh weight }}{0.43 \mathrm{c}}$} & \multirow{2}{*}{$\begin{array}{l}\text { Length } \\
0.72 \mathrm{c}\end{array}$} & \multirow{2}{*}{$\begin{array}{c}\text { Number } \\
0.69 \mathrm{c}\end{array}$} \\
\hline Sucrose (A) & $\left(g \cdot L^{-1}\right)$ & 10 & & & \\
\hline & & 20 & $0.84 b$ & $1.31 \mathrm{~b}$ & $1.08 \mathrm{~b}$ \\
\hline & & 30 & $1.07 \mathrm{a}$ & $1.49 \mathrm{a}$ & $1.18 \mathrm{a}$ \\
\hline & & & $* * *$ & $* * *$ & $* * *$ \\
\hline \multirow[t]{4}{*}{$\mathrm{NH}_{4} \mathrm{NO}_{3}(\mathrm{~B})$} & & 0 & $0.97 \mathrm{a}$ & $1.44 \mathrm{a}$ & $1.16 \mathrm{a}$ \\
\hline & & $1 / 4 \mathrm{MS}$ & $0.81 \mathrm{a}$ & $1.12 \mathrm{~b}$ & $0.98 b$ \\
\hline & & $1 / 2 \mathrm{MS}$ & $0.56 \mathrm{~b}$ & $0.96 c$ & $0.81 \mathrm{c}$ \\
\hline & & & $* *$ & $* * *$ & $* * *$ \\
\hline$A * B$ & & & ns & ns & ns \\
\hline
\end{tabular}

Basal medium supplemented with $3 \mathrm{~g} \cdot \mathrm{L}^{-1}$ Hyponex\#1, $0.1 \mathrm{~g} \cdot \mathrm{L}^{-1}$ citric acid, $1 \mathrm{~g} \cdot \mathrm{L}^{-1}$ tryptonepeptone, $1 \mathrm{~g} \cdot \mathrm{L}^{-1}$ activated charcoal, $8 \mathrm{~g} \cdot \mathrm{L}^{-1}$ agar, $\mathrm{pH} 5.6$.

Concentration of ammonium nitrate $\left(\mathrm{NH}_{4} \mathrm{NO}_{3}\right)$ : $1 / 4 \mathrm{MS}\left(412.5 \mathrm{mg} \cdot \mathrm{L}^{-1}\right), 1 / 2 \mathrm{MS}\left(825.0 \mathrm{mg} \cdot \mathrm{L}^{-1}\right)$.

For each treatment, four replicates of ten protocorm-like bodies (on average $0.15 \mathrm{~g}$ fresh mass) were cultured. Data were scored after three months of culture at $25 \pm 2^{\circ} \mathrm{C}$ with $16 \mathrm{~h}$ light $/ 8 \mathrm{~h}$ dark and photon flux of $22-35 \mu \mathrm{mol} \cdot \mathrm{m}^{-2} \cdot \mathrm{s}^{-1}$.

Values followed by the same letter are not significantly different at $P \leq 0.05$. NS, **, ***: Not significant or significant at $P \leq 0.01$, or 0.001 , respectively (two-way ANOVA, Duncan's multiple range test).

of 20 and $30 \mathrm{~g} \cdot \mathrm{L}^{-1}$ and without additional supplementation of ammonium nitrate were both suitable for plantlet growth in Doritaenopsis Taisuco Ladylip.

\section{Morphological and histological observations of somatic embryogenesis and PLB development}

Continuous subculturing of the initial callus derived from in vitro grown protocorms of the breeding line Doritaenopsis Taisuco Ladylip resulted in the formation of the friable yellowish-white embryogenic callus (Fig. 1A). After transferred to the PLB induction medium and cultured at $25 \pm 2^{\circ} \mathrm{C}$ with $16 \mathrm{~h}$ light $/ 8 \mathrm{~h}$ dark and photon flux of $22-35 \mu \mathrm{mol} \cdot \mathrm{m}^{-2} \cdot \mathrm{s}^{-1}$, the callus gradually turned greenish (Fig. 1B) and then gave rise to some of initial PLBs within two months of culture (Fig. 1C). After three months culture, somatic embryos developed to PLBs with morphological and functional polarity (Fig. 1D). A number of mature PLBs with leaves protruded from the 
tops and rhizoids from the bottoms were clearly visible after five months of culture (Fig. 1E, F). Until sixth month, the true leaves continuously grew and radicles penetrated from the bottoms of PLBs (Fig. 1G, H). PLBs developed into intact plantlets with some leaves and roots within seven months of culture (Fig. 1I).

To determine whether single cells from the friable callus are capable of giving rise directly to somatic embryo, we first focused on the structural changes to the loosely packed callus cells. A brief vortex treatment in liquid medium separated the friable cell masses into small clumps and individual cells. The materials at various regeneration periods were smeared to observe process of somatic embryogenesis by a phase contrast microscope. Isolated single cell (Fig. 2A, left) and two-celled somatic proembryo (Fig. 2A, right), with a smaller terminal cell and a larger basal cell from friable callus, are both observed at the initial stage of differentiation. Derivatives of the terminal cell continue to divide several times and proembryo continues to expand by anticlinal and periclinal divisions (Fig. 2B-D). As development progresses, the proembryo with suspensor cell (Fig. 2E) and the globular proembryo (Fig. $2 \mathrm{~F}-\mathrm{H}$ ) are formed orderly. As it develops further, the somatic embryo becomes elongated and a distinct protoderm is formed (Fig. 2I) and then reaches more mature stage (Fig. 2J) with obvious visible shoot pole.

During the PLB development, secondary PLB can often be observed on the surface of the PLB. Histological studies were also conducted to determine the origin of secondary PLB from PLB. Cross sections of the PLB developed on the Hyponex medium revealed that mitotic divisions occurred in epidermal cells of PLB and resulted in the formation of embryonic origin (Fig. 3A). Continual cell divisions within embryonic origin resulted in the formation of a small protuberance by 8 cells (Fig. 3B) and 16 cells (Fig. 3C). Continual cell divisions within the small protuberance result in the formation of a PLB (Fig. 3D). As it develops further, the PLB reached more mature stage with shoot apex (Fig. 3E) and with distinct leaf primordia (Fig. 3F).
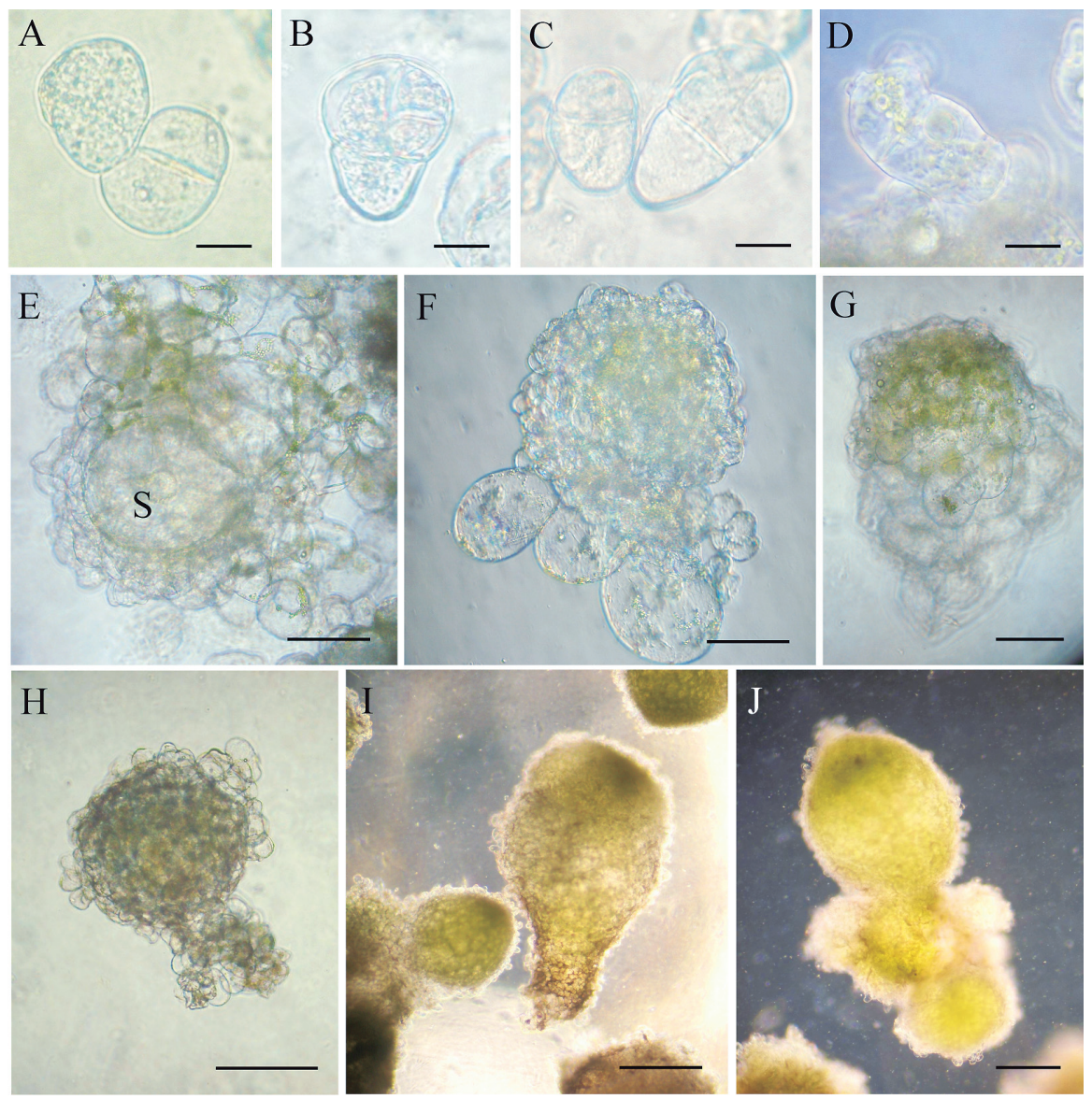

Fig. 2. Somatic embryogenesis from friable embryogenic callus of Doritaenopsis Taisuco Ladylip. (A) Isolated single cell (left) and two-celled somatic proembryo (right) with a smaller terminal cell and a larger basal cell from friable callus. Derivatives of the terminal cell continue to divide and proembryo continues to expand by anticlinal and periclinal divisions (B, C, D). As development progresses, the proembryo with suspensor cell (E) and the globular proembryo (F, G, H) are formed orderly. As it develops further, the somatic embryo becomes elongated and a distinct protoderm is formed (I) and then reaches more mature stage with obvious visible shoot pole $(\mathrm{J})$. Bar $=20 \mu \mathrm{m}$ (A, B, C, D); $50 \mu \mathrm{m}(\mathrm{E}, \mathrm{F}, \mathrm{G}) ; 0.5 \mathrm{~mm}(\mathrm{H}, \mathrm{I}, \mathrm{J})$. 


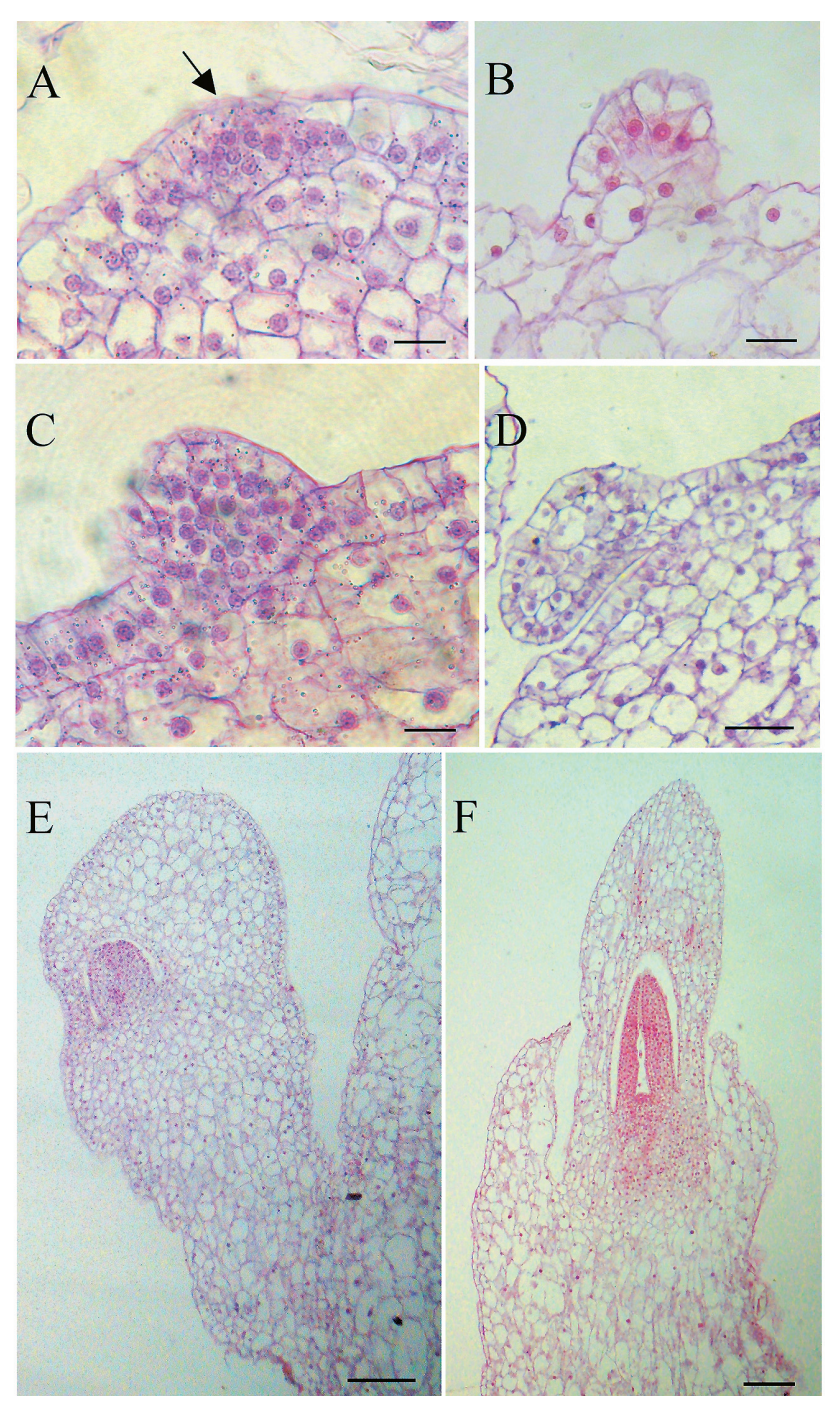

Fig. 3. Light micrographs of the formation of secondary protocorm-like body (PLB) from PLB in Doritaenopsis Taisuco Ladylip. (A) Mitotic divisions occurring in epidermal cells of PLB and formation of embryonic origin (arrow-head). Continual cell divisions within embryonic origin result in the formation of a small protuberance by 8 cells (B) and 16 cells (C). (D) Continual cell divisions within the small protuberance result in the formation of a PLB. (E) PLB with shoot apex $(\mathrm{E})$ and with distinct leaf primordia $(\mathrm{F})$. Bar= $50 \mu \mathrm{m}(\mathrm{A}, \mathrm{B}, \mathrm{C}) ; 100 \mu \mathrm{m}$ (D); $0.5 \mathrm{~mm}(\mathrm{E}, \mathrm{F})$.

\section{DISCUSSION}

BA (benzyl adenine), NAA (naphthalene acetic acid) (Tokuhara and Mii, 2001) or 2,4-D (Ishii et al., 1998) are applied frequently to induce and proliferate callus in Phalaenopsis and in Doritaenopsis (Chowdhury et al., 2003). The experimental results were published that combination of 2,4-D and TDZ was suitable for callus induction and proliferation in Phalaenopsis (Chen et al., 2000). In this experiment, combination of 2,4-D and TDZ also was used to proliferate callus, however 2,4-D in $2 \mathrm{mg} \cdot \mathrm{L}^{-1}$ was benefit of fresh weight gain than in $3 \mathrm{mg} \cdot \mathrm{L}^{-1}$.

A lot of research papers pointed out replacing sucrose of maltose had the better effects in embryogenic callus production (Wang and Wei, 2004), somatic embryogene- sis (Reidiboym-Talleux et al., 1999; Strickland et al., 1987), embryo maturation, and plant regeneration (Druart, 1990; Hristoforoglu et al., 1995; Junaid et al., 2006). In Doritaenopsis, Islam et al. (1999) indicated the callus-derived plant production depends on the components of culture media; for instance, sucrose is suitable for callus proliferation, while maltose and sorbitol are suitable for PLB proliferation. They explicitly deducted that sucrose was easily absorbed and utilized to be advantageous to callus proliferation; but maltose and sorbitol were not easily absorbed and utilized being advantageous to PLB multiplication. Strickland et al. (1987) showed that at equal osmolarity maltose serves to improve yield and development of somatic embryos compared to sucrose and concluded that the maltose effect was primarily nutritional and not osmotically mediated. The effect of maltose on the induction of embryogenesis was specific and can possibly be attributed to its slow hydrolysis by plant cells, exerting starvation conditions early in culture and stable osmolarity of the medium later on (Indrianto et al., 1999). Nørgaard et al. (1997) suggested that the slow metabolism of maltose would lead to sufficient oxygen being present in the cells to allow survival and subsequent somatic embryo development. Drop of carbohydrate availability within the cell may create a signal (Koch, 1996) that will reorientate development program (Blanc et al., 1999).

Trehalose ( $\alpha$-D-glucopyranosyl- $\quad[1,1]-\quad \alpha-\mathrm{D}-$ glucopyranoside) is made of two glucose molecules linked in an alpha-1,1 configuration and thus with no reducing ends Trehalose is a non-reducing disaccharide sugar that is widely distributed in nature (Elbein, 1974), and largely known as a stress protectant and a reserve (Goddijn and van Dun, 1999). Unlike sucrose, trehalose does not constitute a major source of carbon or energy in plants, with its concentration in most cases being at least an order of magnitude lower than that of sucrose (Goddijn and van Dun, 1999). The new conceptual framework to address the mechanisms by which trehalose metabolism and sugar signalling modulate growth and development in plants, trehalose metabolism could play a more direct role in regulating cell division as an integrator of nutritional status and growth (Gómez et al., 2006). In Arabidopsis, addition of even fairly low amounts of external trehalose to the growth medium results in a significant inhibition of seedling root elongation (Wingler et al., 2000). Liu et al. (2006) concluded that trehalose amended NP and $\mathrm{KC}$ media brought about better results than sucrose containing media for PLB proliferation of Phalaenopsis and Doritaenopsis.

In the experiments of somatic embryogenesis in Doritaenopsis Taisuco Ladylip, the strong orientation towards somatic embryogenesis induced with the maltose or trehalose treatments and the opposite effects, i.e., the low orientation towards somatic embryogenesis and callus proliferation was greater, obtained with the sucrose treatment. The somatic embryogenesis induction medium contained maltose or trehalose, rather than sucrose, in equimolarity, this result could be explained by Blanc et al. (2002) indicated the slow growth of the 
maltose treatment was not due to a carbon nutrition deficit, but rather to a specific physiological state due to the cells entering the embryonic pathway.

Sucrose of $20 \mathrm{~g} \cdot \mathrm{L}^{-1}$ and the $412.5 \mathrm{mg} \cdot \mathrm{L}^{-1}$ ammonium nitrate (1/4MS) combined with $3 \mathrm{~g} \cdot \mathrm{L}^{-1}$ Hyponex\#1 was suitable culture medium for Doritaenopsis Taisuco Ladylip plantlet development. Hinnen et al. (1989) indicated that increased $\mathrm{NH}_{4}^{+}$and $\mathrm{NO}_{3}{ }^{-}$concentrations promoted shoot growth, but decreased root growth of Phalaenopsis hybrid seedlings. Hyponex medium was found to be suitable for conversion of PLBs into plantlets and $83 \%$ of PLBs transformed into plantlets on this medium (Young, 2000).

In general, the protocorm is considered as an intermediate structure between the embryo and the plant in Orchidaceae, i.e. protocorm like body is as an intermediate structure between the somatic embryo and the plantlet. Swamy (1949) distinguished embryogeny of the Orchidaceae into two groups according to the presence or absence of a suspensor. The first group is composed in part of Cypripedioideae, the embryo consists mostly of two terminal cells and a middle cell and, to a lesser degree, a suspensor initial which does not contribute much material to the make-up of the embryo. Almost all Orchidaceae species including Phalaenopsis in which the suspensor initial remains distinct and does not participate in the construction of the "mature" embryo belong to the second group (Leroux et al., 1997). Quiroz-Figueroa et al. (2006) pointed out somatic embryos originate by two pathways, unicellular or multicellular, and both direct and indirect somatic embryogenesis embryos can derive from single or various cells. During indirect somatic embryogenesis of Doritaenopsis Taisuco Ladylip, we could observe initial embryogenic single cell of callus proceeding unequal division to form the top and basal end of two-celled stage, succeeded to periclinally and anticlinally divide of the top cell and formed 3-7 cells of embryonal mass. This system where embryos originate from a single cell is a very desirable system for the plant regeneration of genetically transformed cells, and avoiding chimeras. However, the secondary somatic embryos produced during s development in Doritaenopsis Taisuco Ladylip, and the secondary somatic embryos derived from mitotic divisions occurring in PLB epidermal layer through unicellular or multicellular pathway. An embryogenesis secondary system that source of material is somatic embryos can be useful to clone the selected individual after transformation.

In conclusion, we describe the efficient system of Doritaenopsis Taisuco Ladylip that utilizes callus culture and somatic embryogenesis for plant regeneration; a thousand PLBs produce averagely from $1 \mathrm{~g}$ calli after 3 months culture. Maltose and trehalose are being substituted for sucrose, is superior for somatic embryogenesis, and PLBs normally transfer to plantlets on the medium supplemented with Hyponex salts. This system of plant regeneration would be the basis of molecular breeding in Doritaenopsis.

\section{REFERENCES}

Amaki, W. and H. Higuchi. 1989 Effects of dividing on the growth and organogenesis of protocorm-like bodies in Doritaenopsis. Scientia Hortic. 39: 63-72

Arditti, J. and R. Ernst. 1993 Micropropagation of orchids. John Wiley, New York, New York, USA.

Berlyn, G. P. and J. P. Miksche. 1976 Botanical Microtechnique and Cytochemistry, Iowa State University Press, Ames, IA.

Blanc, G., L. Lardet, A. Martin, J. L. Jacob, and M. P. Carron. 2002 Differential carbohydrate metabolism conducts morphogenesis in embryogenic callus of Hevea brasiliensis (Mull. Arg.). J. Exp. Bot. 53: 1453-1462

Blanc, G., N. Michaux-Ferriére, C. Teisson, L. Lardet, and M. P. Carron. 1999 Effects of carbohydrate addition on the induction of somatic embryogenesis in Hevea brasiliensis. Plant Cell Tiss. Org. Cult. 59: 103-112

Chen, Y. C., C. Chang, and W. C. Chang. 2000 A reliable protocol for plant regeneration from callus culture of Phalaenopsis. In Vitro Cell. Dev. Biol.-Plant 36: 420-423

Chowdbury, I., M. Abu Reza Md Rahman, M. Obaidul, and S. Matsui. 2003 Effects of plant growth regulators on callus proliferation, plantlet regeneration and growth of plantlets of Doritaenopsis orchid. Biotech. 2: 214-221

Druart, P. 1990 Improvement of somatic embryogenesis of the cherry dwarf rootstock INMIL/GM9 by the use of different carbon sources. Acta Hort. 280: 125-129

Elbein, A.D. 1974 The metabolism of $\alpha, \alpha$-trehalose. Adv. Carbohydr. Chem. Biochem. 30: 227-256

Ernst, R. 1994 Effects of thidiazuron on in vitro propagation of Phalaenopsis and Doritaenopsis (Orchidaceae). Plant Cell Tiss. Organ Cult. 39: 273-275

Goddijn, O. J. and K. van Dun. 1999 Trehalose metabolism in plants. Trends Plant Sci. 4: 315-319

Gómez, L. D., S. Baud, A. Gilday, Y. Li, and I. A. Graham. 2006 Delayed embryo development in the Arabidopsis trehalose6-phosphate synthase 1 mutant is associated with altered cell wall structure, decreased cell division and starch accumulation. Plant J. 46: 69-84

Hinnen, M. G. J., R. L. M. Pierik, and F. B. F. Bronsema. 1989 The influence of macronutrients and some other factors on growth of Phalaenopsis hybrid seedlings in vitro. Scientia Hortic. 41: $105-116$

Hristoforoglu, K., J. Schmidt, and H. Bolhar-Nordenkampf. 1995 Development and germination of Abies alba somatic embryos. Plant Cell Tiss. Org. Cult. 40: 277-284

Huan, L. V. T., T. Takamura, and M. Tanaka. 2004 Callus formation and plant regeneration from callus through somatic embryo structures in Cymbidium orchid. Plant Sci. 166 1443-1449

Ichihashi, S. 1992 Micropropagation of Phalaenopsis through the culture of lateral buds from young flower stalks. Lindleyana 7: 208-215

Indrianto, A., E. Heberle-Bors, and A. Touraev. 1999 Assessment of various stresses and carbohydrates for their effect on the induction of embryogenesis in isolated wheat microspores. Plant Sci. 143: 71-79

Ishii, Y., T. Takamura, M. Goi, and M. Tanaka. 1998 Callus induction and somatic embryogenesis of Phalaenopsis. Plant Cell Rep. 17: 446-450

Islam, M. O. and S. Ichihashi. 1999 Effects of sucrose, maltose and sorbitol on callus growth and plantlet regeneration in Phalaenopsis, Doritaenopsis and Neofinetia. J. Jpn. Soc. Hort. Sci. 68: 1124-1131

Islam, M. O., M. Abu Reza Md Rahman, S. Matsui, and A. K. M. Azad-ud-doula Prodhan. 2003 Effects of complex organic extracts on callus growth and PLB regeneration through Embryogenesis in the Doritaenopsis orchid. JARQ 37: 229235

Junaid, A., A. Mujib, M. A. Bhat, and M. P. Sharma. 2006 Somatic embryo proliferation, maturation and germination in Catharanthus roseus. Plant Cell Tiss. Org. Cult. 84 
25-332

Koch, K. E. 1996 Carbohydrate-modulated gene expression in plants. Annu. Rev. Plant Physiol. Plant Mol. Biol. 47: 509540

Lee, Y.-I, S.-T. Hsu, and E. C. Yeung. 2013 Orchid protocormlike bodies are somatic embryos. Amer. J. Bot. 100: 21212131

Leroux, G., D. Barabie, and J. Vieth. 1997 Morphogenesis of the protocorm of Cypripedium acaule (Orchidaceae). PI. Syst. Evol. 205: 53-72

Liu, T. H., J. J. Lin, and R. Y. Wu. 2006 The effects of using trehalose as a carbon source on the proliferation of Phalaenopsis and Doritaenopsis protocorm-like-bodies. Plant Cell Tiss. Org. Cult. 86: 125-129

Morel, G. M. 1960 Producing virus-free cymbidiums. American Orchid Society Bulletin 29: 495-497

Murashige, T. and F. Skoog. 1962 A revised medium for rapid growth and bioassays with tobacco tissue cultures. Physiol. Plant. 15: 473-479

Nørgaard, J. V. 1997 Somatic embryo maturation and plant regeneration in Abies nordmanniana LK. Plant Sci. 124: 211-221

Park, S. Y., E. C. Yeung, D. Chakrabarty, and K. Y. Paek. 2002 An efficient direct induction of protocorm-like bodies from leaf subepidermal cells of Doritaenopsis hybrid using thin-section culture. Plant Cell Rep. 21: 46-51

Park, S. Y., H. N. Murthy, and K. Y. Paek. 2003 Protocorm-like body induction and subsequent plant regeneration from root tip cultures of Doritaenopsis. Plant Sci. 164: 919-923

Quiroz-Figueroa, F. R., R. Rojas-Herrera, M. G. Rosa, and V. M. Loyola-Vargas. 2006 Embryo production through somatic embryogenesis can be used to study cell differentiation in plants. Plant Cell Tiss. Organ Cult. 86: 285-301

Reidiboym-Talleux, L., F. Diemer, M. Sourdioux, K. Chapelain, and G. Grenier-De March. 1999 Improvement of somatic embryogenesis in wild cherry (Prunus avium). Effect of maltose and ABA supplements. Plant Cell Tiss. Org. Cult. 55: 199209

Royal Horticultural Society. 2013 Plant registration. http://www. rhs.org.uk/Plants/Plant-science/Plant-registration/Orchids
Strickland, S. G., J. W. Nichol, C. M. McCall, and D. A. Stuart. 1987 Effect of carbohydrate source on alfalfa somatic embryogenesis. Plant Sci. 48: $113-121$

Swamy, B. G. L. 1949 Embryological studies in the Orchidaceae II. Amer. Midl. Nat. 41: 202-232

Tanaka, M, Y. Senda, and A. Hasegawa. 1976 Plantlet formation by root-tip culture in Phalaenopsis. American Orchid Society Bulletin 46: 1022-1024

Tokuhara, K. and M. Mii. 2001 Induction of embryogenic callus and cell suspension culture from shoot tips excised from flower stalk buds of Phalaenopsis (orchidaceae). In Vitro Cell. Dev. Biol.. -Plant 37: 451-461

Tokuhara, K. and M. Mii. 2003 Highly-efficient somatic embryogenesis from cell suspension cultures of Phalaenopsis orchids by adjusting carbohydrate sources. In Vitro Cell. Dev. Biol.Plant 39: 635-639

Tokuhara, K.and M. Masahiro. 1993 Micropropagation of Phalaenopsis and Doritaenopsis by culturing shoot tips of flower stalk buds. Plant Cell Rep. 13: 7-11

Wang, C. T. and Z. M. Wei. 2004 Embryogenesis and regeneration of green plantlets from wheat (Triticum aestivum) leaf base. Plant Cell Tiss. Org. Cult. 77: 149-156

Wingler, A., T. Fritzius, A. Wiemken, T. Boller and R. A. Aeschbacher 2000 Trehalose induces the ADP-glucose pyrophosphorylase gene, ApL3, and starch synthesis in Arabidopsis. Plant Physiol. 124: 105-14

Young, P. S., H. N. Murthy, and P. K. Yoeup. 2000 Mass multiplication of protocorm-like bodies using bioreactor system and subsequent plant regeneration in Phalaenopsis. Plant Cell Tiss. Org. Cult. 63: 67-72

Zhao, P., F. Wu, F. S. Feng, and W. J. Wang. 2008 Protocorm-like body (PLB) formation and plant regeneration from the callus culture of Dendrodbium candidum Wall ex Lindl. In Vitro Cell. Dev. Biol.-Plant 44: 178-185

Zhou, T. S. 1995 In vitro culture of Doritaenopsis: comparison between formation of the hyperhydric protocorm-like-body (PLB) and the normal PLB. Plant Cell Rep. 15: 181-185

Zimmerman, J. L. 1993 Somatic embryogenesis: A model for early development in higher plant. Plant Cell 5: 1411-1423 